\title{
Safety of switching from natalizumab straight into fingolimod in a group of JCV-positive patients with multiple sclerosis
}

\author{
Segurança na mudança direta de natalizumabe para fingolimode em um grupo de \\ pacientes com esclerose múltipla e positivos para JCV \\ Yara Dadalti Fragoso', Soniza Vieira Alves-Leon², Jefferson Becker³, Joseph Bruno Bidin Brooks', Eber \\ Castro Correa $a^{4}$, Alfredo Damasceno ${ }^{5}$, Paulo Diniz da Gama ${ }^{6}$, Rodrigo Assad da Gama ${ }^{6}$, Andre Palma da \\ Cunha Matta', Ernane Pires Maciel ${ }^{8}$, Thereza Cristina d'Avila Winckler ${ }^{9}$
}

\begin{abstract}
Objective: To assess safety of the switch between natalizumab and fingolimod without a washout period. Methods: Prospective data on $25 \mathrm{JCV}$ positive patients who underwent this medication switch were collected and analyzed. Results: After a median period of nine months from the medication switch, there were no safety issues to report. The patients had good disease control and no adverse events were reported. Conclusion: Washout may not be necessary in daily practice when switching from natalizumab to fingolimod. Expertise on multiple sclerosis management, however, is essential for drug switching.
\end{abstract}

Keywords: multiple sclerosis; natalizumab; fingolimod hydrochloride; therapeutics.

\section{RESUMO}

Objetivo: Avaliar a segurança na mudança entre natalizumabe e fingolimode sem período de washout. Métodos: Dados prospectivos de 25 pacientes positivos para vírus JC que tiveram sua medicação modificada foram coletados e analisados. Resultados: Após uma mediana de nove meses da troca de medicação, não havia aspectos de segurança a relatar. Os pacientes estavam com bom controle da doença e não foram relatados eventos adversos. Conclusão: Washout pode não ser necessário na prática diária para a mudança entre natalizumabe e fingolimode. No entanto, expertise no manejo de esclerose múltipla é essencial para esta troca entre medicações.

Palavras-chave: esclerose múltipla; natalizumab; cloridrato de fingolimode; terapêutica.

Natalizumab and fingolimod are both efficient and safe treatments when used at the appropriate time in multiple sclerosis (MS). Peculiarities regarding the safety aspects of these drugs make it ideal for them to be administered by physicians who are familiar with the potential adverse events and know how to avoid them. Natalizumab is an efficient drug for treating MS. This monoclonal antibody is used in the form of monthly infusions and has remarkable effects on the activity of the disease, such that it maintaining
MS under control in a large majority of patients ${ }^{1}$. The major concern when using natalizumab for longer periods is the potential for development fatal progressive multifocal leukoencephalopathy (PML) in association with JCV+ status. Because of the risk of developing PML or due to suboptimal response to this treatment, some patients are withdrawn from natalizumab after a period of using $i^{2}$. When natalizumab is withdrawn, there is a serious risk of severe disease reactivation ${ }^{3}$ and there are no specific protocols to follow

\footnotetext{
'Universidade Metropolitana de Santos, Departamento de Neurologia, Santos SP, Brasil;

${ }^{2}$ Universidade Federal do Estado do Rio de Janeiro, Departamento de Neurologia, Rio de Janeiro RJ, Brasil;

${ }^{3}$ Pontifícia Universidade Católica do Rio Grande do Sul, Departamento de Neurologia, Porto Alegre RS, Brasil;

${ }^{4}$ Clinica de Neurologia e Endocrinologia (CLINEN), Departamento de Neurologia, Brasília DF, Brasil;

5Universidade Estadual de Campinas, Departamento de Neurologia, Campinas SP, Brasil;

${ }^{6}$ Pontifícia Universidade Católica Sorocaba, Departamento de Neurologia, Sorocaba SP, Brasil;

${ }^{7}$ Universidade Federal Fluminense, Departamento de Neurologia, Niterói RJ, Brasil;

${ }^{8}$ Hospital de Base do Distrito Federal, Departamento de Neurologia, Brasília DF, Brasil;

๑Universidade Positivo, Departamento de Neurologia, Curitiba PR, Brasil.

Correspondence: Yara Dadalti Fragoso; Rua da Constituicao 374;11015-470 Santos SP Brasil; E-mail:yara@bsnet.com.br

Conflict of interest: There is no conflict of interest to declare.

Received 13 January 2016; Received in final form 23 May 2016; Accepted 24 May 2016
} 
in this situation ${ }^{4}$. Fingolimod is considered to be the best alternative for patients who are ceasing to use natalizum$\mathrm{ab}^{5}$, but the washout period between the two drugs is still a matter of controversy. It is considered that patients who switch from natalizumab to another drug continue to run the risk of PML during the overlap period between the two drugs, since natalizumab takes 56 days $^{6}$ to 200 days $^{6}$ to be cleared out of the patient's serum. Because of this overlap, caution has been recommended by panels of experts, particularly when the patient is $\mathrm{JCV}+{ }^{7}$. After the initial recommendations for a six-month washout period, other proposals emerged and there is now no doubt that the shorter the washout period is, the less the chance of disease reactivation will $\mathrm{be}^{7,8}$. In fact, shorter periods seem to have an even better effect on disease control without compromising safe$t^{9}$. At present, the recommendations are that there should be 8 to 12 weeks of washout between these drugs, and the rate of reactivation is still high in the literature. The aim of the present study is to provide data on $25 \mathrm{JCV}+$ patients who had four to eight weeks of washout period, without any drug given during this time.

\section{METHODS}

This study was approved by the Ethics Committee of Universidade Metropolitana de Santos, Brazil, under the Certification of Ethical Presentation and Approval (CAAE) no. 05669912.3.0000.5509. Data were collected prospectively from patients who ceased using natalizumab and started treatment with fingolimod, at all of the nine MS units participating in this project. The period between the drugs was four to eight weeks ( from the time of the last infusion of natalizumab to the time of administration of the first capsule of fingolimod). No cases were lost to follow-up. This was an observational and open study, and every participating neurologist took his/her own decision on how long the washout should be (between four and eight weeks), considering that there were no specific guidelines to follow. Sample size was calculated as 23 patients aiming for $95 \%$ confidence and $5 \%$ error.

\section{RESULTS}

Twenty-five patients entered the study. There were 20 females and 5 male subjects, with a median age of 40 years. All the patients were JCV+. The median duration of treatment with natalizumab had been 29 months (range: 10 to 55 months) at the time of the drug switch. For 15 patients, the first dose of fingolimod was administered at the time of completing four weeks since the last infusion of natalizumab. The median duration of treatment with fingolimod was 13 months at the time when the data were collected (range: nine to 26 weeks).

The average time that elapsed between treatments was $5.6 \pm 2.0$ weeks (median $=$ four weeks). One patient had previously had tuberculosis and required maintenance of isoniazid treatment throughout natalizumab and fingolimod administration. One patient suffered a fall followed by seizures, but no evidence of PML was observed. This patient later evolved to secondary progressive MS and is, at present, without immunomodulatory or immunosuppressive treatment. No other noteworthy adverse events or specific features were observed.

All patients showed complete control of the disease without relapses, and without lesion enlargement or new lesions on MRI. Disability, as assessed by the expanded disability scale score (EDSS) ${ }^{10}$, was unaltered after the drug switch (average EDSS $=3.6$ before the switch and 3.5 at the last consultation).

\section{DISCUSSION}

Natalizumab is an excellent choice for treating highly active MS, but it may be necessary to withdraw this treatment at a given point. Fingolimod is the best choice for the drug switch $^{8}$. Expert recommendations that are not evidencebased state that there must be a washout period of three to six months before fingolimod is started. The recurrence of disease activity among such patients undergoing long followup periods has been very high'.

In conclusion, in order to control disease activity, a maximum interval of eight weeks between the two treatments seems to be a safe and efficient way of dealing with natalizumab withdrawal.

\section{References}

1. Derfuss T, Kuhle J, Lindberg R, Kappos L. Natalizumab therapy for multiple sclerosis. Semin Neurol. 2013;33(1):26-36. doi:10.1055/s-0033-1343793

2. Tur C, Montalban X. Natalizumab: risk stratification of individual patients with multiple sclerosis. CNS Drugs. 2014;28(7):641-8. doi:10.1007/s40263-014-0168-0

3. Baumgartner A, Stich O, Rauer S. Clinical and radiological disease reactivation after cessation of long-term therapy with natalizumab. Int J Neurosci. 2012;122(1):35-9. doi:10.3109/00207454.2011.622452

4. Capobianco M, di Sapio A, Malentacchi M, Malucchi S, Matta M, Sperli F et al. No impact of current therapeutic strategies on disease reactivation after natalizumab discontinuation: a comparative analysis of different approaches during the first year of natalizumab discontinuation. Eur J Neurol. 2015;22(3):585-7. doi:10.1111/ene.12487

5. Stüve O, Cravens PD, Frohman EM, Phillips JT, Remington GM, Geldern $G$ et al. Immunologic, clinical, and radiologic status 14 months after cessation of natalizumab therapy. Neurology. 2009;72(5):396-401. doi:10.1212/01.wnl.0000327341.89587.76

6. Rispens T, Vennegoor A, Wolbink GJ, Polman CH, Killestein J. Natalizumab remains detectable in patients with multiple sclerosis long after treatment is stopped. Mult Scler. 2012;18(6):899-901. doi:10.1177/1352458511431073 
Kappos L, Radue EW, Comi G, Montalban X, Butzkueven H, Wiendl $\mathrm{H}$ et al. Switching from natalizumab to fingolimod: A randomized, placebo-controlled study in RRMS. Neurology. 2015;85(1):29-39. doi:10.1212/WNL.00000000000001706

8. laffaldano P, Lucisano G, Pozzilli C, Brescia Morra V, Ghezzi A, Millefiorini E et al. Fingolimod versus interferon beta/glatiramer acetate after natalizumab suspension in multiple sclerosis. Brain. 2015;138(11)3275-86. doi:10.1093/brain/awv260
9. Fragoso YD, Adoni T, Alves-Leon S, Apostolo-Pereira SL, Araujo YR, Becker $J$ et al. Alternatives for reducing relapse rate when switching from natalizumab to fingolimod in multiple sclerosis. Exp Rev Clin Pharmacol. 2016;9(4). doi:10.1586/17512433.2016.1145053

10. Kurtzke JF. Rating neurologic impairment in multiple sclerosis: an expanded disability status scale (EDSS). Neurology. 1983;33(11):1444-52. doi:10.1212/WNL.33.11.1444 